\title{
Spontaneous peritonitis and bacteremia caused by Streptococcus equinus: Value of $16 S$ rRNA gene sequencing analysis
}

\author{
John Dotis ${ }^{1}$, Nikoleta Printza ${ }^{1}$, Stella Stabouli ${ }^{1 *}$, Efthymia Petinaki $^{2}$ and Fotios Papachristou $^{1}$ \\ ${ }^{1} 1$ st Department of Pediatrics, Aristotle University, Hippokratio Hospital, Greece \\ ${ }^{2}$ Department of Microbiology, University Hospital of Larissa, Greece
}

\begin{abstract}
Streptococcus equinus constitutes an uncommon Gram-positive cocci that can cause infections in humans rarely. We have recently encountered a case of $S$. equinus peritonitis, established by $16 \mathrm{~S}$ rRNA gene sequence analysis, in a peritoneal dialysis (PD) patient which, in our knowledge, is the first reported case in a PD child complicated with bacteremia.
\end{abstract}

\section{Introduction}

Streptococcus equinus is Gram-positive cocci, catalase negative, which has seldom been reported to cause infections in humans [1]. Even rarer are the peritonitis cases presented in the bibliography in previous decades [2,3]. We have recently encountered a case of $S$. equinus peritonitis in a peritoneal dialysis (PD) patient that, in our knowledge, is the first reported case in a PD child complicated with bacteremia.

\section{Case report}

A 9-year old boy who had end stage renal disease, due to infantiletype polycystic kidney disease, was treated with continuous ambulatory PD from the age of 10-months old. He was admitted to the hospital with cloudy effluent, fever $\left(39^{\circ} \mathrm{C}\right)$, vomiting and diarrhea. Empirically treatment with intraperitoneal (i.p.) vancomycin $(30 \mathrm{mg} / \mathrm{L})$ plus ceftazidime $(125 \mathrm{mg} / \mathrm{L})$ was initiated in addition to intravenous (i.v.) cefouroxime $(50 \mathrm{mg} / \mathrm{kg})$. The PD fluid obtained, was slightly opalescent, and was sent immediately to the microbiological laboratory for further analysis. In parallel, blood cultures were also obtained. The PD fluid analysis revealed the presence of 650 cells $/ \mu \mathrm{L}$ with $85 \%$ neutrophils, while, Gram stain was negative for microorganism. PD fluid was injected into both aerobic and anaerobic blood culture bottles which were processed by automated BACTEC 9120 System (Becton Dickinson). Furthermore, $20 \mathrm{ml}$ of the PD fluid was collected in rubber sealed pyrogen-free tubes for direct detection of bacterial DNA (Endo Tube ET; Chromogenix AB, Vienna, Austria). A broad-range 16S rRNA PCR with subsequent DNA sequencing, detecting bacterial DNA directly in clinical specimens of patients with serious infections is applied on a routine basis. The isolation and the detection of bacterial DNA in the PD fluid were performed as previously reported [4]. The PCR amplicons ( $520 \mathrm{bp}$ ) were sequenced in both directions by the same pair of primers used for amplification, in an ABI PRISM310 automated sequencer according to the manufacturer's instructions, and the obtained sequences (approximately $460 \mathrm{bp}$ ) were compared with $16 \mathrm{~S}$ rRNA sequences available, both with the advanced BLAST search.
Specifically, primers 5'-GACGAACGCTGGCGGCGTGCCTA-3' and 5'-CGCTCGTTGCGGGACTTAACC-3' were used. Analysis of the sequences results demonstrated $100 \%$ identity of the microorganism with Streptococcus equines (Gen Bank accession No KJ803948.1) and was available one day after admission (Figure 1).

Three days after admission and two days after the molecular

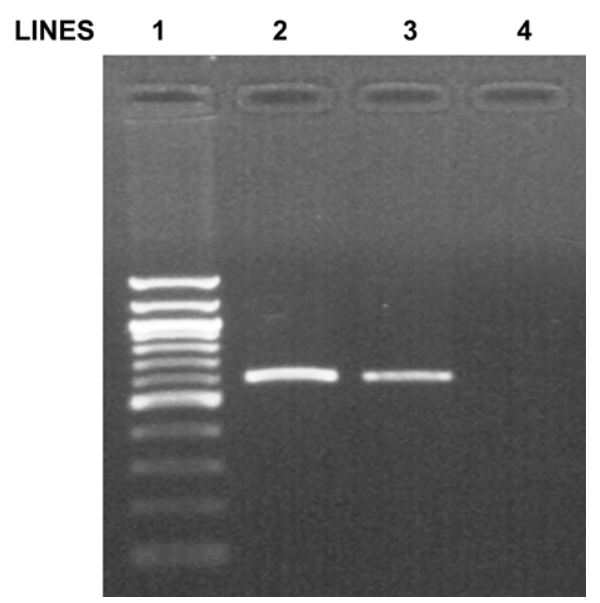

Lane 1, ladder 10.000bp; Lane 2, our Streptococcus equinus isolate; Lane 3, positive control; Lane 4, negative control

Figure 1. Detection of the Streptococcus equinus isolate with DNA sequencing initial PCR fragment on agarose gel.

Correspondence to: Stella Stabouli, MD, PhD, 1st Department of Pediatrics, Hippokratio Hospital, Konstantinoupoleos 49, 54642 Thessaloniki, Greece, Tel:0030 2310892466, Fax: 0030 2310992784, E-mail: sstaboul@auth.gr

Key words: Streptococcus equinus, $16 \mathrm{~S}$ rRNA analysis, peritonitis, bacteremia

Received: January 30, 2017; Accepted: February 16, 2017; Published: February 18,2017 
detection, the PD fluid culture similarly to the blood cultures demonstrated the presence of a Gram-positive cocci, catalase negative, which was identified as $S$. equinus by the automated system VITEK 2 (bioMérieux, Marcy l'Etoile, France). Susceptibility testing was performed by agar diffusion method according to CLSI guidelines. The isolate was resistant to erythromycin (MIC: $6 \mathrm{mg} / \mathrm{L}$ ), cefuroxime (MIC: $4 \mathrm{mg} / \mathrm{L}$ ) and inducible resistant to clindamycin (MIC: 0.064 $\mathrm{mg} / \mathrm{L}$ ). In addition, was found to be sensitive to ceftriaxone (MIC: 0.19 $\mathrm{mg} / \mathrm{L}$ ), cefepime (MIC: $0.125 \mathrm{mg} / \mathrm{L}$ ), daptomycin (MIC: $0.38 \mathrm{mg} / \mathrm{L}$ ), meropenem (MIC: $0.023 \mathrm{mg} / \mathrm{L}$ ), vancomycin (MIC: $0.25 \mathrm{mg} / \mathrm{L}$ ) and linezolid (MIC: $2 \mathrm{mg} / \mathrm{L}$ ). Systemic antibiotic treatment was switched to ceftriaxone $(75 \mathrm{mg} / \mathrm{kg})$ and i.p. treatment was continued with vancomycin monotherapy. After a total of 14 days with combined systemic antibiotic and i.p. treatment, the patient fully recovered without catheter replacement or any clinical sign of sepsis. Throughout peritonitis course, CAPD was continued without ultrafiltration problems. When reviewed one week, one month and 6 months after the end of treatment, he was well without any signs or symptoms of peritonitis.

\section{Discussion}

Streptococcus equinus is a Lancefield group D streptococcus which belongs to Streptococcus bovis/equinus-complex and the taxonomy of this complex has undergone several changes during the last decade. Specifically by $16 S r R N A$ gene sequence analysis, was divided into S. equinus, Streptococcus bovis, Streptococcus gallolyticus subsp. gallolyticus, Streptococcus infantarius subsp. coli, Streptococcus infantarius subsp. infantarius, Streptococcus pasteurianus, Streptococcus gallolyticus subsp. macedonicus, Streptococcus alactolyticus and Streptococcus lutetiensis $[5,6]$.

Published cases of human infections due to S. equinus are rare with only two peritonitis cases presented till now. In the first case, a patient with cirrhosis developed spontaneous bacterial peritonitis plus bacteremia and was treated with aztreonam [2]. The second case was in a 63-year-old man with end-stage renal disease of unknown origin treated with CAPD. The isolate was identified as a S. equinus by an API 32 (bioMerieux, Lyon, France) automated identification system and the patient was treated with i.p. cefalotin for a total of 14 days [3]. However, $16 \mathrm{~S} r R N A$ gene sequence analysis was not available for both cases.

The scarcity of reports concerning S. equinus infections may be due to low pathogenicity, but it also may be due to difficulties in culturing and identifying the bacteria. If it is available a $16 S r R N A$ gene sequence analysis is useful to establish certain biotypes and subspecies when a $S$. equinus is isolated from a culture, and although S. equinus is rare as a cause of human infections, it is very easy to be treated even in severe cases of both bacteremia and peritonitis such in our case.

\section{References}

1. Klein RS, Catalano MT, Edberg SC, Casey JI (1980). Streptococcus equinus septicemia: report of two cases and review of the literature. Am J Med Sci 279: 99. [Crossref]

2. Ariza J, Gudiol F, Dolz C, Xiol J, Liñares J, et al. (1986) Evaluation of aztreonam in the treatment of spontaneous bacterial peritonitis in patients with cirrhosis. Hepatology 6: 906-910. [Crossref]

3. Tuncer M, Ozcan S, Vural T, Sarikaya M, Süleymanlar G, et al. (1998) Streptococcus equinus peritonitis in a CAPD patient. Perit Dial Int 18: 654. [Crossref]

4. Gatselis N, Malli E, Papadamou G, Petinaki E, Dalekos GN (2006) Direct detection of Cardiobacterium hominis in serum from a patient with infective endocarditis by broadrange bacterial PCR. J Clin Microbiol 44: 669-672.

5. Schlegel L1, Grimont F, Ageron E, Grimont PA, Bouvet A (2003) Reappraisal of the taxonomy of the Streptococcus bovis/Streptococcus equinus complex and related species: description of Streptococcus gallolyticus subsp. gallolyticus subsp. nov., $S$. gallolyticus subsp. macedonicus subsp. nov. and S. gallolyticus subsp. pasteurianus subsp. nov. Int J Syst Evol Microbiol 53: 631-645. [Crossref]

6. Jans C, Meile L, Lacroix C, Stevens MJ (2015) Genomics, evolution, and molecula epidemiology of the Streptococcus bovis/Streptococcus equinus complex (SBSEC) Infect Genet Evol 33: 419-436. [Crossref]

Copyright: (C2017 Dotis J. This is an open-access article distributed under the terms of the Creative Commons Attribution License, which permits unrestricted use, distribution, and reproduction in any medium, provided the original author and source are credited. 